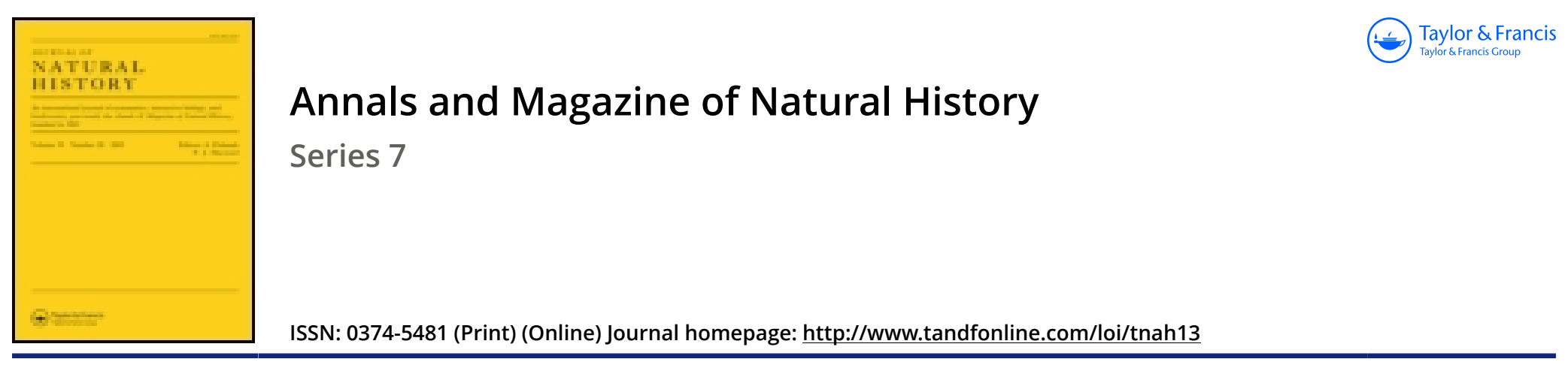

\title{
XLIX.-On Felis ocreata, better known as Felis caligata, and its subspecies
}

\section{Harold Schwann}

To cite this article: Harold Schwann (1904) XLIX.-On Felis ocreata, better known as Felis caligata, and its subspecies, Annals and Magazine of Natural History, 13:78, 421-426, DOI: 10.1080/00222930408562473

To link to this article: http://dx.doi.org/10.1080/00222930408562473

曲 Published online: 29 Sep 2009.

Submit your article to this journal

LII Article views: 3

Q View related articles $\asymp$ 
nutwards from the middle of the antero-internal peninsula towards the centre of the main dentine area of the tooth, dying away about halfway across to the hinder margin. This additional complexity of the incisive section has not been hitherto noticed in any hare.

Dimensions of the type (measured in the flesh) :-

Head and body $390 \mathrm{~mm}$; tail 90 ; hind foot 115 ; ear 115 .

Skull : back of parietals to tip of nasals 78 ; basilar suture to henselion 55; zygomatic breadth 39 ; nasals, length diagonally 34 , greatest breadth 18 ; interorbital breadth 20 ; diastema 23 ; breadth of palatal bridge 7 ; palatal foramina $21 \times 9$.

Hab. (of type). Ambaca. Alt. $800 \mathrm{~m}$.

Type. Adult female. B.M. no. 4. 4. 9. 140. Original number 7. Collected 29th April, 1903.

The Angolan hare was referred by Prof. Bucage to Lepus ochropus, Wagn., but that is the yellow-naped High Veldt representative of $L$. capensis *. Jentink's $L$. salce, from Mossamedes, is a far paler form, with much shorter tail.

Probably L. angolensis is most nearly allied to the Zambesian $L$. Whytei, but differs from that as from all other spocies by the unusual complexity of its upper incisors.

\section{Procavia Bocagei, Gray. \\ १. 51 (imm.). Pungo Andongo.}

XLIX.-On Felis ocreata, better known as Felis caligata, and its Subspecies. By Harold Schwann.

THE first account of this cat appears in Bruce's 'Travels to Discover the Source of the Nile' + , under the name of the "Booted Lynx," and, with the exception of the exaggeration of the ear-tufts in the plate, appears to be a very accurate description.

In $1791 \mathrm{E}$. W. Cuhn published at Leipzig a German translation of the 'Travels,' with a zoological appendix by J. F. Gmelin, where the latter distinctly gives the name of Felis ocreata $\ddagger$ to Bruce's specimen.

$F$. ocreata therefore stands as being the earliest technical name of the species.

* Cf. Ann. \& Mrg. Nat. Hist. (7) xii. p. 344 (1903).

$\dagger$ Vol. v. p. 146 (1790).

$\ddagger$ Ainh. Bruce Reisen, Gmel. p. 27 (1791).

Ann, \& Mag. N. Hist. Ser. 7. Vol. xiii. 
Mr. W. E. de Winton, in Anderson's 'Zoology of Egypt' *, has taken Meyer's Felis lybica $†$ as representing Bruce's "Booted Lynx," not having noticed Gmelin's earlier name. It seems, however, very probable that Meyer's $F$. lybica is applicable to some form of caracal, as the first part of the description he quotes from Forster's translation of Buffon $\ddagger$ (the original describer) runs as follows:- "Corpore rufo, auriculis albis nigrobarbatis."

The names that have been applied to this group at different times are given below, with the locality where each type was collected, so far as this can be ascertained with any exactness:-

“Booted Lynx," Bruce, Travels Source of the Nile, vol, v. p. 146 (1700). - Ras el Feel, A byssinia.

Felis ocreata, Gmelin, Anh. Bruce, Reisen (Rinteln und Leipzig), vol. ii. p. 27 (1791). Felis cafra, Desm. Encycl. Méth., Mamm. Suppl. p. 540 (18פ2).-

Felis caligata, Temm. Monogr. Mamm. no. 4, vol. i. p. 123, 1824 (182T) (ex Bruce).

Felis maniculata, Tenm. op. cit. p. 128.-Ambuknk, on the Nile.

Felis Rïppelli, Schinz, Cuv. Thier. vol. iv. p. 509 (1825).-Dongola.

Felis buhastis and F. dongolance (nom. nud.), Hemp. \& Ehrenb. Symb. Phys. dec. ii. text to pl. xvii. (1832).

Felis pulchella, Gray, Charlesw. Mag. Nat. Hist. i. p. 577 (1837).-Egrypt. Felis margarita, Loche, liev, et Mag. Zool. p. 49 (1858).-N'gonca, Algerian Sahara.

Felis cristata, Lataste, Faune des Vert. de Barbarie, p. 104 (1885).Haidra.

It appears very probable that $F$. pulchella ought to be considered a synonym of $F$. maniculata, Temm., but the British Museum does not at present possess sufficient NorthAfrican material to settle the question definitely.

I regard the following new forms as subspecies partly hecause their differences from Felis ocreata are not marked enough to warrant specific distinction, and also on account of the great convenience the use of trinomial nomenclature is in linking together the members of a widely distributed group.

Felis ocreata rubida, subsp. n.

Resembles $F$. o. ocreata in general proportions, but is strongly suffused with fulvous on the head, body, and feet.

General colour of the upper surface "hair-brown," the

* P. 171 .

† Meyer, 'Syst. Zool. Entd. Neuholland u. Afr.' p. 101 (1793).

\pm Forster, 'Ueberf. v. Buff. Naturgesch. der vierfüssigen 'I'hiere,' B. ri. p. $313(1780)$. 
median line strongly fulvous, pencilled with black; flanks covered with irregular brown spots. Individual hairs of back about $15 \mathrm{~mm}$. in length ; their basal third drab, middle third cinnamon-colour, subterminal ring dark brown, almost black, tip buffy. Muzzle, upper lip, ears, and sides of throat bright fulvous; a white patch above and below the eyes, nape dark brown; four indistinct brown lines extending from forehead to shoulders ; interramia pure white, shading into dull buffy on the throat and chest; belly cinnamon-colour, marked with indistinct black spots ; inguinal region buffy yellow. Upper surface of fore and hind limbs light brown, ringed with several indistinct brown bands; forearms partially black; feet fulvous above, black beneath; tail coloured like back, tip black, three or four subterminal black rings.

Dimensions of the type (from the dried skin):-

Head and body $575 \mathrm{~mm}$.; tail 286 ; hind foot 127 ; ear 54 .

Skull : basilar suture to nasion 60.5 ; breadth of braincase 44.2 ; temporal breadth 30.6 ; anteorbital breadth 14.0 ; zygomatic breadth 62.0 ; outer length of upper carnassial 10.7; greatest length of auditory bulla $22 \cdot 0$.

Hab. Monbuttu.

Type. Male. B.M. no. 87. 12. 1.6. Collected and presented by Dr. Emin Pasha.

A young specimen obtained by Dr. Emin from the same locality has the characteristic spots on the flanks and the fulvous coloration on the median line, but is of a rather lighter colour throughout.

Felis ocreata Mellandi, subsp. n.

Very uniformly coloured, no spots or bands on the back and sides.

General colour of the upper surface greyish buff, darker on the median line. Individual hairs of back about $35 \mathrm{~mm}$. in length; basal two thirds dull buffy yellow; subterminal ring black; tip light grey. Under surface creamy buff; the hairs grey basally, middle third buff, terminal third creamy yellow. Nose and ears bright yellowish; cheeks and interramia light yellow, almost white; forehead and nape darker than back, the individual hairs black, with grey tips. Upper surface of fore and hind limbs coloured like back; under surface black, speckled with grey.

The two specimens of this subspecies in the British Museum are incomplete as to their tails, so it is impossible to say whether the usual black tip and subterminal rings are present until more material is obtained. The tail (as $29 *$ 
much as is preserved) is coloured like the median line of the back, rather darker than the flanks.

Dimensions of the type (from the dried skin) :-

Head and body $210 \mathrm{~mm}$.; ear 48.

Skull absent in both specimens.

Hab. Mpika, North-east Rhodesia.

Type. B.M. no. 4. 3. 11.2. Collected and presented by F. H. Melland, Esq.

I have much pleasure in naming this cat after Mr. Melland, who has collected a number of specimens for the National Museum in the country round Mpika.

This subspecies may be readily distinguished by the sharp contrast between the bright yellow of the ears and the rest of the body as well as the entire absence of any markings on the dorsal area.

A specimen collected by Mr. Alfred Sharpe in 1893 * at Lake Mweru appears to be referable to Mellandi.

Felis ocreata uganda, subsp. n.

Similar to $F$. o. ocreata, but darker throughout.

General colour above yellowish grey, lighter on the flanks; median line of the back conspicuously darker, fulvous to dark brown; flanks transversely banded with indistinct fulvous stripes from ten to fifteen in number. Underfur of back about $15 \mathrm{~mm}$. in length, proximal half smoke-grey, light buffy yellow distally; long hairs about $25 \mathrm{~mm}$. in length, black, with white subterminal ring and black tip. Under surface "creamy buff," covered irregularly with brown or blackish spots. Muzzle, upper lips, and a patch above and below the eyes strongly fulvous; a line extending from the posterior margin of the orbit to the middle of the cheek dark brown; edge of the lips, lower part of the cheek, and a patch from muzzle to eyebrows yellowish white; forehead and nape darker than the back, in well-marked specimens nearly black; ears bright rufous, covered internally with long white hairs, ear-tufts black ; interramia and throat white, with one or two transverse buffy yellow bands; inguinal region thickly covered with long buffy hair. Upper surface of fore and hind limbs coloured like back, with several indistinct dark bands; feet bright buffy above, black below. Tail coloured like back or greyer; two or three black subterminal rings; tip black.

Dimensions of the type (taken in the flesh) :-

Head and body $584 \mathrm{~mm}$.; tail 341 ; hind foot 131 ; ear 58 . * P. Z. S. 1893, p. 723. 
Sliull.

\begin{tabular}{|c|c|c|}
\hline & $\begin{array}{c}\text { Male (type). } \\
\text { mm. }\end{array}$ & $\begin{array}{c}\text { Female. } \\
\text { num. }\end{array}$ \\
\hline Greatest length & $\ldots 103 \cdot 0$ & $92 \cdot 0$ \\
\hline Basal length & $88 \cdot 0$ & $78 \cdot 5$ \\
\hline Zygomatic breadth & $73 \cdot 0$ & $63 \cdot 2$ \\
\hline Anteorbital breadth. & $16 \cdot 5$ & $16 \cdot 0$ \\
\hline Temporal breadth ... & $31 \cdot 2$ & $35 \cdot 6$ \\
\hline Brain-case, breadth & $45 \cdot 5$ & $45 \cdot 0$ \\
\hline Greatest length of bulla & 24.0 & 230 \\
\hline Outer length of upper carnassial... & $11 \cdot 0$ & $11 \cdot 0$ \\
\hline
\end{tabular}

ITab. Mulema, Uganda.

Type. Male. B.M. no. 3. 11. 7. 8. Alt. 5000 feet. Collected by Mr. W. G. Doggett and presented by Col. Delmé Radcliffe.

The comparative skull-measurements given above serve very well to show the difference in size between the sexes. The specimens from which they were taken were both fully adult and obtained in the same locality.

'The colour of the female is slightly lighter throughout, agreeing in this respect with a specimen obtained by Capt. Speke at "Memissa."

\section{Feilis ocreata cafra, Desm.*}

Mr. W. E. de Winton, in Anderson's 'Zoology of Egypt' †, decided that it was necessary to adopt the earlier name of obscura instead of cafra for the South-African race of Felis ocreata, although the name was based on a melanistic specimen. A comparison of the two descriptions with the British Museum's fine series of South-African skins seems to suggest that after all Desmarest's $F$. obscura $\S$ may be nothing more than a melanistic specimen of the domestic cat. It may be noticed that the British Museum specimens do not have the "bandes transversales entièrement noires et très-nombreuses," nor is the species so small as the domestic cat, as $F$. obscura is said to be.

It appears, therefore, so doubtful whether $F$.obscura is really referable to this species that I see no necessity at present for altering the more suitable and better known name of cafra.

The British Museum does not at present possess sufficient North-African material for me to decide detinitely as to the status of $F$. margarita, Loche, and $F$. cristata, Lataste.

* Encycl. Méth., Mamm. Suppl. 1822, p. 540.

$\dagger$ P. 175 .

I Eneycl. Méth., Mamm. 1820, p. 230.

$\S$ See 1ict. des Sci. nat., F. Cur., tom. viii. p. 222, for original description. 
A synopsis of the new forms described above is added to assist in the identification of individual members of this difficult group :-

A. No fulvous suffusion on the sides, no spots on the flanks.

a. Underfur on median line of back cinnamon-colour, forehead and nape not darker than back ......

b. Underfur on median line dark brown or black, forehead and nape darker than back.

$a^{\prime}$. Forearms conspicuously ringed with black, underside of forearms deep black all over ....

$\boldsymbol{b}$. Forearms inconspicuously ringed, underside of forearms partially black.

$a^{\prime \prime}$. General colour pale, ears yellowish .......

$b^{\prime \prime}$. General colour darker, ears rufous .......

B. Sides and limbs suffused with fulvous, well-marked

brown spots on the flanks................

F. o. ocreata.

F. o. cafra.

F. o. Mellandi.

F. o. uganda.

F. o. rubida.

\section{L.-On certain A frican Butterflies of the Suhfamily}

Pierinæ. By Arthur G. Butler, Ph.D., F.L.S., \&c.

I THINK every true naturalist will agree with me that fair criticism is valuable as a stimulus, and has the effect of making a good workman exert himself to avoid error as much as possible in his subsequent work. When, however, a man has spared no pains to arrive at the exact truth, has built up his facts brick by brick, until the edifice seems to be complete, and another workman, with all the facts before him, misrepresents them, it seems only right to expose the unfairness of such criticism.

In a paper by Prof. Aurivillius published in the Upsala 'Nya Tidnings Aktiebolag' last year, and entitled "Results of the Swedish Zoological Expedition to Egypt and the White Nile, 1901, under the direction of L. A. Jägerskiöld. -No. 8," the author records two forms of Belenois under the names Pieris gidica, God., var. Westwoodi, Wallengr., and Pieris gidica, God., var. (?) abyssinica, Lucas; and he observes, "It is very remarkable that $W$ estwoodi also was taken in the dry season at nearly the same time as abyssinica. The relation between $P$. Westwoodi and abyssinica has been the subject of much discussion, and is not yet sufficiently cleared up. Butler says in 1894 (Proc. Zool. Soc. 1894, p. 579), 'I am quite satisfied that $B$. gidica and $B$. abyssinica cannot be regarded as distinct species'; and in 1898 (Trans. Fint. Soc. London, 1898, p. 436), 'I may begin by stating 